\title{
Social Support and Future Optimism of Adolescent at Salatiga Islamic Orphanage
}

\author{
I'anatul Khasanah" ${ }^{*}$, Nanik Prihartanti ${ }^{2}$, Marwanto $^{3}$ \\ 12Pascasarjana UMS Surkarta, 3IAIN Salatiga, Indonesia
}

\begin{abstract}
Generally, teenagers in an orphanage have had problems with their environment, friends, and society. So that they have low optimism in facing their future. This study aims to determine whether there is a relationship between social support and optimism for the future of adolescents in the Salatiga Islamic orphanage. The research subjects were adolescents at the Salatiga Islamic orphanage who were taken using a purposive sampling technique with a total of 120 subjects, consisting of $52.5 \%$ boys and $47.5 \%$ girls. The data was collected using a social support scale and a future optimism scale. Data analysis was processed using statistical regression analysis techniques. The analysis showed a significant positive relationship between social support and optimism for the future of adolescents in the orphanage.
\end{abstract}

Keywords: optimism; social support; orphanage

\begin{abstract}
Abstrak
Remaja di panti asuhan pada umumnya pernah mempunyai masalah terhadap lingkungannya, teman, dan masyarakat. Sehingga mempunyai optimisme yang rendah dalam menghadapi masa depannya. Penelitian ini bertujuan untuk mengetahui apakah ada hubungan antara dukungan sosial dan optimisme masa depan remaja di panti asuhan Islam Salatiga. Subyek penelitian adalah remaja di panti asuhan Islam Salatiga yang diambil dengan menggunakan teknik purposive sampling dengan jumlah subjek 120 orang, terdiri atas 52,5\% remaja laki-laki dan 47,5\% remaja perempuan. Pengumpulan data dilakukan dengan menggunakan skala dukungan social dan skala optimisme masa depan. Analisis data diolah dengan teknik statistik analisis regresi. Hasil analisis menunjukkan hubungan positif signifikan antara dukungan sosial dan optimism masa depan remaja di panti asuhan.
\end{abstract}

Kata Kunci: optimism; dukungan sosial; panti asuhan 
Introduction

Protection of orphans using an orphanage. The orphanage is an institution in charge of teaching and providing services to orphans, who are unable and neglected so that their learning capacity returns to normal and can be expanded widely. An orphanage is also an institution that functions to accommodate orphaned children (losing one or both parents).

Orphanages in the context of state social services are state obligations as stipulated in article 34 of the 1945 Constitution (Ningrum, 2012). Orphans and abandoned children are in orphanages because they are helpless and cannot develop themselves, one of which is because they live in a poor family (Triastuti, Mulyadi, \& Fauziah, 2012). Orphanages are the final place of choice to save their future, as well as being the best place for families who cannot afford the pattern of care.

They are in an orphanage because they are economically incapable, unable to get care such as orphaned, orphaned, or orphaned, unable to get good protection and security, such as being abandoned or abandoned by their parents. When in an orphanage with a new environment and family and increasing age, it does not mean that the problem is also resolved, sometimes new problems come.

Adolescents in orphanages tend to have inferior, passive, apathetic, withdrawn, easily discouraged, full of fear and anxiety, have difficulty establishing social relationships with other people, and some people still think negatively of the orphanage (Aidina, Nisa, and Sulistyani, 2013). Also, they often experience rejection, quit school, move houses, and separate from friends and relatives (Mutambara, 2015). In the end, they feel unsure whether they can continue their schooling due to limited costs and this causes a pessimistic attitude towards their 
future (Wahid et al. 2018). Orphaned and abandoned children feel helpless because they live in poor families and cannot develop themselves (Empati \& Lupitasari, 2017). Adolescents in orphanages have minimal experience and parenting styles, the environment is different from at home, and socio-economic problems make them tend to be low (Citra, 2015).

The results of interviews with five adolescents who live at the Putri Aisiyah Orphanage in Yogyakarta also show a pessimistic attitude towards the future, something that has often appeared in thoughts (Suseno, 2013). The child living in the orphanage has pessimism about his future. They are pessimistic about whether they can get good nurturing or can they guarantee a better future for their life later. The results also revealed that $46 \%$ of adolescents in the orphanage are pessimistic and have low self-identity (Marwati, Prihartanti, \& Hertinjung, 2013). Teens who are in the orphanage feel they have no identity, and become a new source of conflict for their environment, they are separated from the people they are close to, complain easily, and often have problems expressing emotions in negative rather than positive ways.

The orphanage children feel pessimistic about reaching their goals. In his mind, all expenses from others did not belong to him. They also feel whether they can be like children outside who are always there and sufficient every day. All that is needed is to ask and grant it by the parents.

The factors that influence the low optimism of the orphaned children include, among others, the fact that almost all orphaned children come from underprivileged and problematic families, unfavorable cultural culture, and a lack of companions who are in charge 
I'anatul Khasanah, Nanik Prihartanti, Marwanto

of assisting or caring for them so that the orphanage children feel less attention (Nurindah, Afiatin, \& Sulistyarini, 2012). This problem makes them pessimistic (Salamah, 2018). Adolescents who live in orphanages are generally caused by underprivileged families, orphans, orphans, orphans, families who experience problems or obstacles in educating their children, and families who are not harmonious or have broken relationships among family members (broken home) or more famous. in panic referred to as dhuafa family. They feel inferior, lack selfconfidence, have negative feelings, are passive towards others, and find it difficult to socialize.

Based on the description above, social support is a predictor of adolescent optimism. Social support is important to research because it is expected to contribute to optimism for the future of adolescents. Optimism is very important because an ideal or hope will be realized when it is done with a positive mood, feeling of happiness, and joy towards positive expectations.

\section{Future Optimism of Adolescent}

\section{Optimism}

Optimism is defined as a general expectation of positive experiences rather than negative experiences in the future (Joshi and Srivastava, 2009). Optimism is a positive vision of individual satisfaction in achieving future goals in several programs (Salamanca, 2014). Optimism is a tendency to expect good and see events and situations positively (Hasnain, 2014). Optimism is people expecting something positive to happen to them (Bulls \& Bulls 2014). Optimism refers to two concepts, the tendency to hope and the tendency to believe that humans live the best life in this world ini (Pi, Gagea, \& 
I'anatul Khasanah, Nanik Prihartanti, Marwanto

Mihaela 2014). Optimism is a trend that is expected to be profitable in the future and has positive results on circumstances and spends time actively dealing with and overcoming stress (Sabouripour, 2015). Optimism is closely related to adolescents because it is related to motivation and generosity in facing and solving problems. How to grow and create optimism for adolescents living in orphanages.

\section{Factors of Optimism}

According to Seligman (1991), factors that influence future optimism are self-confidence, self-esteem, accumulated success experiences, social support (Aisyah, dkk., 2015). The factors that influence optimism in adolescent social institutions are external factors in the form of environment and internal factors, namely from within themselves or personally (Nurindah, Mutya, \& Afiatin, 2012).

\section{Aspects of Optmism}

Seligman (2008) found three aspects of optimism, namely, 1) permanent / seeing events based on time, 2) pervasive / viewing events in terms of scope, and 3) personal / source or cause of an event (Ushfuriyah, 2013).

\section{Optimism theory}

This optimism theory uses the theory of motivation or better known as the expectance value theory. This theory argues that individual behavior is structured by two aspects, namely goals or goals are states or actions that are considered, desired or unwanted, and expectations are confidence or doubt in achieving goals (Tita, 2016). 
Social Support

\section{Social support}

Social support is generally defined as the range of interpersonal relationships or connections that have an impact on individual functioning and generally includes support provided by individuals and by social institutions (Barker, 2007). Cobb said social support as a person's belief to be cared for and loved, valued and respected, obliged and communicated (Parkinson's, 2016). Meanwhile, Carlson \& Perrewe stated that social support refers to interpersonal transactions that involve emotional attention, instrumental assistance, information or judgment (Tamer \& Dereli, 2014).

\section{Factors of Social Support}

Sarafino (1994) suggests three factors that cause individuals to receive support, namely: 1) Potential Recipients of Support. Social support can occur if you have social relationships, need help, and there is openness. 2) Potential Support Providers. Individuals who should be providers of support are people who have social relationships, are willing to think about other individuals, or are aware of the needs of others. 3) Composition and Structure of Social Networks. A social network is a link between a person and people in their family and environment, it can take various forms, relationship closeness, composition (family, friends, coworkers, etc.), and closeness of the relationship (Ushfuriyah, 2013).

\section{Aspects of Social Support}

Schneiders (1964) divided into three aspects, namely social adjustment in the home and family environment, a social adjustment 
in the school environment, and social adjustment in the community (Maslihah, 2011).

Based on the background of the problem, this study takes the following problem formulations: Is there a relationship between social support and optimism for the future of adolescents in the orphanage. While the purpose of this study is the relationship of social support and optimism for the future of adolescents in the orphanage. There have been many types of research on optimism, however, there have not been many that have examined the relationship between social support and optimism for the future of teenagers in orphanages. Here are some previous studies.

Research conducted by Ushfuriyah (2013) used 20 young men and women aged 13-18 years with variables dependent on optimism and variables dependent on social support (Ushfuriyah, 2013). This study produces a positive relationship between social support and optimism. The social support received from various sources and different types of support provide better benefits as the result of Astuti and Hartanti's research. This study used optimism dependent variables and social support dependent variables with 6 students of the Faculty of Psychology UNDIP as subjects (Astuti \& Hartati, 2013).

Based on the novelty description, none of these studies have similarities with the author's research, so the research "Social Support and Future Optimism of Adolescent at Salatiga Islamic Orphanage" has never been researched before and the originality of this study can be justified. 
Methodology

\section{Data Collection Methods and Tools}

This research uses a correlational quantitative approach with a purposive sampling technique. The data collection method in this study used a social support and optimism scale. The data in this study were collected using an instrument in the form of a research questionnaire that had been used in previous research. The research variable consisted of the independent variable, namely social support, and the dependent variable, namely optimism.

The scale consists of social support and optimism. The data in this study were collected using an instrument in the form of a research questionnaire that had been used in previous research. The social support scale uses a questionnaire in previous research that has been declared valid and reliable (Khoir, 2018), and the Optimism scale uses the same questionnaire in previous research that has been declared valid and reliable (Susatyo, 2016). Thus the research instrument does not need to test the validity and reliability test anymore.

\section{Population, Sample, and Sampling}

The population in this study consisted of all residents of Islamic orphanages in the city of Salatiga with the following criteria, male and female adolescents aged 15-18 years, active in school, and living in the Salatiga orphanage. Based on the characteristics of the population, the population in this study were 120 teenagers in the Salatiga Islamic orphanage. This sampling technique used purposive random sampling and this study determined the number of samples to 120 people. 
I'anatul Khasanah, Nanik Prihartanti, Marwanto

Result and Discussion

This research took place in the city of Salatiga by involving foster children who were in the Aisyiyah orphanage, Daarul Hadlanah orphanage, Muhammadiyah Soka orphanage, Abu Hurairah Muhammadiyah Kauman, and the Sudirman Tingkir Islamic orphanage. The number of respondents was 120 foster children.

Based on the percentage calculation, it shows that the number of respondents is 120 , consisting of male respondents as much as $52.5 \%$ or 63 children and female respondents by $47.5 \%$ or as many as 57 children. The respondents were spread across five Islamic orphanages in Salatiga. SMA became the most respondents, namely $71.6 \%$ or as many as 86 children, followed by SMK $16.7 \%$ or as many as 20 children, and SMP $11.7 \%$ or as many as 14 children.

Respondents or foster children in an orphanage with an average age of 18 years were $37.5 \%$, then 17 years old was $28.3 \%$, 16 years old was $22.7 \%$, and 15 years old was $11.7 \%$. Most of the status in the orphanage is more dominated by the poor or underprivileged children with a percentage of $56.7 \%$, then orphaned by $20 \%$, orphaned by $16.6 \%$, and the least is orphaned at $6.7 \%$.

Before data analysis is performed, first the normality and linearity tests are carried out. Both tests were carried out using the help of the SPSS program. The normality test is carried out to determine whether the data residuals are normally distributed. This test uses the Kolmogorov-Smirnov test, with the criteria that if the significance is greater than 0.05 , the data is declared to be normally distributed.

Normality Test of Kolmogrov-Smirnov

\begin{tabular}{llll}
\hline Variable & Kolmogrov-Smirnov Z & Sign & Information \\
\hline $\begin{array}{l}\text { Unstandardzed } \\
\text { Residual }\end{array}$ & 0,747 & 0,05 & $\begin{array}{l}\text { Distributed } \\
\text { Normal }\end{array}$ \\
\hline
\end{tabular}


Primari data sourse that are processed

A linearity test is used to see whether the model specifications used are correct or not. Whether the function used in an empirical study should be linear or non-linear.

Linierity Test of Kolmogrov-Smirnov

\begin{tabular}{|c|c|c|c|c|}
\hline No & Variable & F & Sig & $\begin{array}{c}\text { Informatio } \\
\mathbf{n}\end{array}$ \\
\hline 1 & Optimistic-Social support & 1,686 & 0,044 & Linear \\
\hline
\end{tabular}

The results of this study indicate that there is a significant relationship between social support and optimism for the future of adolescents in the orphanage. This means that it can be concluded that the major hypothesis is accepted.

Teenagers must be able to see themselves as dignified individuals. He must be able to respect himself, meaning that positive thinking is the key to his development. Social support can make a positive contribution to adolescents in orphanages. Administrators, managers, and friends at the orphanage and the surrounding community must work together to provide enthusiasm and support for their future development. A conducive situation or atmosphere will provide comfort and safety for teenagers living in the orphanage to grow and develop like teenagers in general. Creating an atmosphere that can nurture and protect them. Adolescents in orphanages have good self-esteem because they get social support from inside and outside the orphanage, which creates selfconfidence for them. All of this will make teenagers optimistic in facing the future in the orphanage.

Based on the results of the $\mathrm{X}$ and $\mathrm{Y}$ tests, it shows a partial correlation of $0.12, p=0.019(p>0.01)$, which means that it shows a 
positive and insignificant relationship between social support and optimism. The higher the social support, the higher the level of adolescent optimism. In reality, teenagers in orphanages need support from various parties. The real support, of course, comes from the orphanage and their families. This is by the motivational theory that the higher the social support, the higher the future optimism of adolescents in the orphanage.

The research above is supported by Sarason in Kuntjoro (2002) which states that social support is the existence, willingness, concern of others to be able to respect and love each other (Ushfuriyah, 2013). Maslihah added that social support is the comfort, attention, appreciation, or assistance that a person gets from his interactions with other people (Maslihah 2011).

Orphanage children must feel comfortable and safe living in an orphanage. So their existence must be cared for and cherished. In the sense of being well cared for and always given motivation and support so that in reaching his future in the orphanage he feels optimistic.

Furthermore, Appearance (2017) mentions the importance of social support in adjusting to difficult conditions. When conditions are difficult, efforts must be made to increase social support and the ability to be optimistic. This means that no matter how difficult it is, support that can provide enthusiasm and that support is also able to give strength to that person is needed. Meanwhile, social support that is felt to play an important role must be done in the relationship with the optimistic personality type (Chapman \& Chi, 2016). They will always face difficulties of various kinds, from family, economy, and education. Her presence in the orphanage must be better and more comfortable so that they feel at home while living there for their future. 
The important role of social support for those who need it is to support assistance for those who are teenagers in orphanages. Support from various parties is needed and recommended. The orphanage must be able to provide the best support for the sustainability of foster children, both physically and spiritually. Physical needs include food, clothing, and shelter, while spiritual needs are more on the tranquility, comfort, and conduciveness of the places where they live so far. Families must encourage and motivate the importance of looking to the future for a longer life than just at home and not fulfilling all needs, especially education, even though they have to live separately from their families, namely in an orphanage.

\section{Conclusion}

Based on the results of data analysis and the discussion that has been described, it can be concluded that self-esteem, social support, selfconfidence, and optimism determine the level of future optimism for adolescents in the orphanage, so the major hypothesis states that there is a significant positive relationship between social support and optimism. the future of youth in an orphanage is acceptable.

There is an insignificant relationship between social support and optimism. Supposedly, the higher the social support, the higher the optimism level of adolescents and vice versa. There is a significant relationship between self-confidence and optimism for the future of adolescents in the orphanage. The higher the self-confidence, the more optimistic the teenager will be.

The optimism category of teenagers in the orphanage, both optimism and social support, fall into the medium category. It is hoped that the caregivers will always motivate and support the teenagers in the 
I'anatul Khasanah, Nanik Prihartanti, Marwanto orphanage so that they can grow and be able to increase their sense of optimism in facing the future. The management must make the orphanage a comfortable and safe place and adequate facilities for the development of adolescents in the orphanage in achieving optimism for their future. Meanwhile, for future researchers, this research can be a reference for further research, especially those with the theme of social support with optimism. 


\section{Bibliography}

Aidina, W., Haiyun, N., \& Arum, S. (2013). Hubungan Antara Penerimaan Diri Dengan Optimisme Menghadapi Masa Depan Pada Remaja Di Panti Asuhan. Jurnal Psikohumanika, VI(2), 1-12. https://www.researchgate.net/publication/325944169

Aisyah, S., Yuwono S., \& Zuhri, S. (2015). Hubungan Antara Self-Esteem Dengan Optimisme Masa Depan Pada Siswa Santri Program Tanfidz Di Pondok Pesantren Al-Muayyad Surakarta Dan Ibnu Abbas Klaten. Indigenous: Jurnal Ilmiah Psikologi, 13(2), 1-8.

Astuti, T., \& Hartati, S. (2013). Dukungan Sosial Pada Mahasiswa Yang Sedang Menyusun Skripsi (Studi Fenomenologis Pada Mahasiswa Fakultas Psikologi Undip).Jurnal Psikologi, 12(1), 113. https://doi.org/10.14710/jpu.12.1.1-13

Barker, G. (2007). Adolescents, social support and help-seeking behaviour: an international literature review and programme consultation with recommendations for action/ Gary Barker. World Health Organization. https://apps.who.int/iris/handle/10665/43778

Goodin, B.R., \& Bulls, H.W. (2013). Optimism and the Experience of Pain:

Benefits of Seeing the Glass as Half Full. Curr Pain Headache Rep, 17, 329. https://doi.org/10.1007/s11916-013-0329-8

Chapman, T., \& Chi, T. (2016). Perceived Social Support Mediates the Association Between Optimism and Active Coping. Northwestern Review, 1(1).

Citra, A. F., \& Widyarini, N. MM. (2015). Pelatihan Peningkatan Harga Diri Pada Remaja Panti Asuhan Sub Unit Perlindungan Sosial Asuhan Anak, Cibalagung, Bogor. Jurnal Psikologi 8(2), 91-103.

Lupitasari, N., \& Fauziah, N. (2018). Hubungan Antara Harga Diri Dengan Kecenderungan Perilaku Prososial Pada Remaja Panti Asuhan di 
Semarang. Jurnal EMPATI, 6(3), 318-322. from https://ejournal3.undip.ac.id/index.php/empati/article/vie $\mathrm{w} / 19761$

Hasnain, N. (2014). Optimism, Hope, and Happiness as correlates of Psychological Well-Being among Young Adult Assamese Males and Females. IOSR Journal of Humanities and Social Science, 19, 44-52. https://doi.org/10.9790/0837-19224452

Tamer, İ., \& Dereli, B . (2014). The Relationship Between Interpersonal Trust, Peer Support And Organizational Commitment. Öneri Dergisi, 11(42), 175-196. DOI: 10.14783/od.v11i42.5000065518

Joshi, S., \& Srivastava. R (2009). Self-Esteem and Academic Achievement of Adolescents. Journal of the Indian Academy of Applied Psychology, 35, 33-39.

Marwati, E., Prihartanti, N., \& Hertinjung, W. S. (2013). Pelatihan Berfikir Optimis Untuk Meningkatkan Harga Diri Pada Remaja Di Panti Asuhan. Jurnal Indegenous, 1(1), 23-31. DOI: https://doi.org/10.23917/indigenous.v1i1.1790

Maslihah, S. (2012). Studi Tentang Hubungan Dukungan Sosial, Penyesuaian Sosial Di Lingkungan Sekolah Dan Prestasi Akademik Siswa Smpit Assyfa Boarding School Subang Jawa Barat. Jurnal Psikologi, $10(2)$, $103-$

114. https://doi.org/10.14710/jpu.10.2.103-114

Mutambara, J. (2015). Behavior Enhancing Psychosocial Support through

Positive Youth Development: Narratives from Orphans in Zimbabwe. Journal of Child and Adolescant Behaviour 3(6), 1-7. http://dx.doi.org/10.4172/2375-4494.1000264

Ningrum, N. A. (2012). Hubungan Antara Coping Strategy Dengan Kenakalan Pada Remaja Awal. Jurnal Psikologi Tabularasa, 
7(1):481-89.

Nurindah, M., Afiatin, T., \& Sulistyarini, I. (2012). Meningkatkan Optimisme Remaja Panti Sosial Dengan Pelatihan Berfikir Positif. Jurnal Intervensi Psikologi, 4(1), 57-76. https://doi.org/10.20885/intervensipsikologi.vol4.iss1.art4 Parkinson's. (2016). The Importance of Social Support. Parkinson's New Zealand, 19(1).

Paunescu, C., Piţigoi, G., Gabriela, G., \& Paunescu, M. (2014). Study on the Self-Evaluation of Self-Esteem among Young Adults. Procedia Social and Behavioral Sciences, 117(2014), 705-709. DOI: $10.1016 / j . s b s p r o .2014 .02 .286$

Sabouripour, F., \& Roslan, S. (2015). Resilience, Optimism and Social Support among International Students Resilience, Optimism and Social Support among International Students. 11(15), 159-170. DOI: $10.5539 /$ ass.v11n15p159

Salamah, H. N. (2018). Upaya Pembimbing Dalam Membentuk Sikap Optimisme Remaja Di Panti Asuhan Putri Muhammadiyah Purwokerto. IAIN Purwokerto. http://lib.iainpurwokerto.ac.id//index.php?p=show_detail\&id=3 7203

Pérez, C. L., Salamanca, M. V., Castañeda, I. A., Soto, P. B., Vanegas, I. J. (2014). What Makes Us Optimistic?: Psychosocial Factors as Predictors of Dispositional Optimism in Young People. Terapia Psicológica, 32(2), 153-164.

Suseno, M. N. (2013). Efektivitas Pembentukan Karakter Spiritual Untuk Meningkatkan Optimisme Terhadap Masa Depan Anak Yatim Piatu. Jurnal Intervensi Psychology, 5(1), 1-24. https://doi.org/10.20885/intervensipsikologi.vol5.iss1.art1 
I'anatul Khasanah, Nanik Prihartanti, Marwanto

Tita, R. D. (2016). Optimisme Pada Penderita Kanker Serviks Di RSUD Prof. Dr. Margono Soekarjo Purwokerto. Skripsi UMP.

Triastuti, S., Mulyadi., Fauziah P. (2012). Peranan Panti Asuhan Dalam Pemberdayaan Anak Melalui Ketrampilan Sablon. DIKLUS: Jurnal Pendidikan Luar Sekolah, 16(2), 121-133..

Ushfuriyah. (2013). Hubungan Antara Dukungan Sosial Dengan Optimisme Mahasiswa Psikologi UIN Maulana Malik Ibrahim Malang Dalam Menyelesaikan Skripsi.

Wahid, A. W., Larasati, A., Ayuni., \& Nashori, F. (2018). Optimisme Remaja Yang Tinggal Di Panti Psuhan Ditinjau Dari Kebersyukuran Dan Konsep Diri. Humanitas, 15(2), 160-68. http://dx.doi.org/10.26555/humanitas.v15i2.8725 